\title{
Index in Alexandre Dumas' Novel the Man in the Iron Mask: A Semiotic Analysis
}

\author{
Salmia Syarifuddin ${ }^{1}$, Andi Rukayah Alim Yahya ${ }^{1}$, Kamaruzaman Jusoff ${ }^{2} \&$ Abdul Makhsud $^{3}$ \\ ${ }^{1}$ Department of English, Faculty of Letters, Universitas Muslim Indonesia, Indonesia \\ ${ }^{2}$ Department of Forest Production, Faculty of Forestry, Universiti Putra Malaysia, Malaysia \\ ${ }^{3}$ Mechanical Engineering Department, Faculty of Engineering, Universitas Muslim Indonesia, Indonesia \\ Correspondence: Kamaruzaman Jusoff, Department of Forest Production, Faculty of Forestry, Universiti Putra \\ Malaysia, 43400 UPM Serdang, Selangor, Malaysia. Tel: 603-89-467-176. E-mail: kjusoff@yahoo.com
}

Received: June 22, 2013 Accepted: July 31, 2013 Online Published: September 4, 2013

doi:10.5539/elt.v6n10p228 URL: http://dx.doi.org/10.5539/elt.v6n10p228

\begin{abstract}
Novel as a literary work can be analyzed by using semiotic analysis. This article aims to analyze the meaning of index found in characterizations in the novel the Man in the Iron Mask by Alexandre Dumas. This article involved the descriptive qualitative method. The results revealed that there are many causal relations between the index and the characterization of the characters found in that novel. It contained 24 characterizations from eight major and five minor characters that had been representative of this article. From this article, it is obtained more information about the identified characterizations found in the novel and its index analysis that showed its causalities relation between the sign and the object (index and characterization) in a more comprehensive meaning. Since semiotics is the study of signs and novel is a literary work, it is recommended to English literature lecturers and students to enrich knowledge of analyzing literary works through semiotic analysis.
\end{abstract}

Keywords: semiotic, novel, the man in the iron mask, index, sign, characterization

\section{Introduction}

\subsection{Semiotic as a Study in Literary Work}

Novel is a part of literary work which tells a story about life, such as a social problem in a certain society where the author lives. In analyzing a literary work like novel, it is suggested to start it through the intrinsic or extrinsic aspects of the novel. Characterization is one of the elements of intrinsic aspects of novel. This characterization comes from the psychological development of the character which appears in the series event or its plot. Novel is also usually called as world of words. Words in novel include as structure of signs which have the meaning. Thus, it is believed that signs are connected to semiotic.

Semiotic as the study of signs classifies signs into icon, index and symbol. This classification based on Peirce's theory of semiotic. Index can be found and analyzed in characterization of the novel. In the comprehensive meaning shows that, index is the sign which explains the causalities relation between object and its signs. The signs show that index can be found in the characterization of the novel. The signs which give index that the characters depend on the characterizations can be searched in the novel whether it is major or minor characters. Therefore in a literary research using semiotic approach, it is found that index is the sign which is the most interested and the most wanted to be researched.

This article attempted to show the analysis of indexes of the characterizations found in the novel the Man in the Iron Mask by Alexandre Dumas. The indexes of characterizations were taken from the major and minor characters in the novel as the object of semiotic study. It is expected to be useful and helpful information for everyone who interests and wants to know more about the index analysis of characterizations found in the novel. The analysis was restricted to the intrinsic aspect of the novel particularly to characterization and its indexes analysis as a sign in semiotic.

\subsection{The Role of Semiotics in Novel}

The study of semiotic especially by using literary work as object had been done by Masters as cited in Norgaard (2009) that as part of its meaning-making, novel contains facsimile reproductions of a number of entries from 
Stuart's private diary in the novel Stuart. A Life Backwards. This is a fairly simple example of indexical meaning where the look of the writing invokes the material origin of its own coming into being.

Novel as a literary work had been explained by experts of literature. The word novel was befallen from Roman or Latin Novellus which came from the word novies that meant "new". It was new because if it was compared with another literary works such as drama and poetry, novel appeared in coming days. Liddel as cited in Tarigan (1984), the first born England's novel was Pamela in 1740. There are two kinds of characters in intrinsic aspects of literary work particularly to novel; the first is major character who always appears in the novel until the novel comes to its resolution. While another one is minor character that means who seldom appears in the novel. Character is the person in the novel who reflects social life and true picture of life. Then in the real life, there is a mutual assistance between people, and they influence one another for better or worse. Each of character has its own characterization. The character may have more than one of characterizations in accordance with the possibility of characterization which exists in human being, such as cruel, patient, coward, good, honest, and etc. The changing of the characters, whether in positive or negative are called character development. The most important is the suitability between the characters and its development where the development here means characterization with purpose or mission needed to achieve.

In the plot, characterization would appear when character showed the social role. Therefore, this characterization is the psychological side of the character appears when the character comes to its development through the plot in the novel (Ratna, 2004). The pattern of the character's action was influenced by temperament. Characterization is character's temperament which appeared in the story (Atmazaki, 1990). This temperament can change and may be constant depend much on the form of the character's struggle. May be in the first of his struggle he was wise, but when he had faced a challenge, he would change more seriously. The impression he floated, the exchange of his attitude and temperament is called characterization.

There are two kinds of characterizations. The first one is flat character that means the character of the person who has one or few dominant traits. Flat characters are two-dimensional "types" outlined without detail. A single idea or quality dominates them, so that they can be expressed in one sentence or two. It is usually a minor character in a novel. Another one is round character which is complex character in temperament and motivation and represents his environment. It is a greater achievement than a flat character. Round character must be himself, an individual, can be changed the protagonist manner in each chapter, he becomes wiser and more tolerant.

The characterizations as the source of indexes were found in the novel the Man in the Iron Mask written by Alexandre Dumas. The story inside the Man in the Iron Mask is a sub-plot and third part of the longer Dumas novel the Vicomte de Bragelonne, third in the D'artagnan romances (the three musketeers, twenty years after). It follows a conspiracy to depose Louis XIV, King of France, with his imprisoned twin brother, Philippe, the mysterious "Man in the Mask" (http://www.barnesandnoble.com/w/the-man-in-the-iron-mask-by-alexandre-dumas-alexandre-dumas/110913662 3\#). This novel was not the first fictional work based on the Iron Mask legend, but Dumas' the Man in the Iron Mask became the best-known version of the old tale. His most successful novels were not deep, but contained marvelous adventures and actions.

Semiotic as the study of signs that analyzed in this article is actually found in our daily life. Human life is filled by signs. Every day in our life we consume signs. Even crying, speaking, laughing, it is all indicating as signs. Wannisinghe also stated that semiotics involves not only what we refer to as signs in everyday speech, but anything which stands for something else (Wannisinghe, 2011). Thus, we can communicate each other with signs' intercession and the life process will be more efficient. According to Charles Sanders Peirce (Sobur, 2004), semiotic is "a relationship among a sign, an object, and a meaning."

A sign may be simple or complex. Unlike Saussure, Peirce does not define the sign as the smallest unit of signification. Anything or phenomenon, no matter how complex, may be considered as a sign from the moment it enters into a process of semiosis (Desmedt, 2011). Thus, it is clear that sign is a concept or idea that appears in commentator's mind refers to the pointed object. In his book Cours de Linguistique Generale, published in 1916 (Cobley, 1997) Saussure mentioned that sign has two sides; signifier is a material aspect from sign, such as a cat or handwriting while signified is a concept of mentality. When we mention the word 'cat' from signifier (/c/a/t/), what appears in our mind is not the 'real' cat, but a concept of the cat; such as, has four legs, mew, like eating fish, a beautiful animal, etc.

If Saussure divided signs in two sides, Peirce divided it into three sides or triadic. They are representament (the firstness), object (the secondness), and interpretant (the thirdness). Based on the object is a concept which is recognized by the user of the sign related to the representament. It is also included as semiotic process in a half 
way (R-O) (Christomy, 2004). Then, signifier is the sign vehicle while the signified is the meaning. In this theory, things have no place but words acquire meaning as they enter a system of relations (Jegede, 2003).

Thus, signifier and signified cannot be separated and related one another. Object may be 'like' some other representations already held in thought because this new semiotic stimulus seems to conjure up those similar signs (Mackey, 2012). Mackey's statement is in line with Peirce's theory of semiotic that emphasized in signs based on objects.

The relationship between signifier and signified consist of three forms, (Atmazaki, 1990), as follows:

1) Signifier is a description of the direct meaning from signified (icon), such like photo.

2) Signifier is the result (causal relation) from the signifier (index), such as smoke from the fire.

3) Signifier is not the result, the cause or the direct description from signified, but something which related conventionally and arbitrary (symbol).

Based on the two expert's statements above which are different opinion one another, thus this article is intended to Peirce theory. Among representament, object, and interpretant, the most often be analyzed is object. Then among icon, index and symbol, index is sign that mostly analyzed in the literary works, particularly to novel.

As one of Peirce' triadic, index is included in object (referenced) that explains the relation between sign and the object because of causalities relation, such as fire and smoke (Ratna, 2004). Boulton also stated in his online journal that an index signs is a sign where there is a direct link between the sign and the object (Boulton, 2005). The explanations above have explained that the sign, in this case, smoke is caused by the fire. Another example like the existence of the wet ground is caused by the rainfall. It is in line with Norgaard statement that the meaning-potential of the index resides in a basically physical and causal relation between the signifier and the signified, as in the archetypical examples of the relation between smoke and fire, and between a footprint and the person who made the footprint (Norgaard, 2009).

Semiotic analysis can also be applied to communication and information representation in contexts of various media (Shitemi, 2009). In literary research by using semiotic approach, index is the most hunted sign to be researched. This index shows the causalities relation in a broader meaning (Sobur, 2004). We can find it in characterization of novel, whether that is major or minor character. For an instance, in the characterization of a policeman, index as a semiotic sign can be searched to proof that the character is a truly police. Performed text integrates the reader's oral text, the author's written text, and the illustrator's visual text. From this view, the narrow conception of text as author's text is thus extended into the sphere of the social on context of the reading event where the text is a display of author's, illustrator's, and performer's cues (Golden, 1990). Based on the related research articles analyzed semiotic in literary works, hence, this article aims to analyze the meaning of index as a sign in semiotics found in characterizations in the novel the Man in the Iron Mask by Alexandre Dumas.

\section{Method}

The method used in this article was descriptive qualitative method. It was focused on characterizations in analyzing indexes of characterizations found in the novel "the Man in the Iron Mask" by Alexandre Dumas. The major characters consisted of eight characters with 16 characterizations while minor characters consisted of five characters with eight characterizations. The characterizations were the representative samples.

\section{Results and Discussion}

The Index Analysis of Characterizations of Major Characters: The character of Louis XIV has two characterizations. In characterization as King of France found three signs that give index that Louis XIV is the King of France (page 16). Why he is mentioned as the King of France (page 285), because he is a son of Anne of Austria, the queen mother in the monarchy (page 285). Louis XIV was the first child of her. As the first child, he was automatically heir to the throne of France monarchy. The second sign gives index is a crown. A king must and surely has and wears a crown (page 550) as a sign (index) shows that he is the king. It is also a characteristic that the king has. The third sign is sire (page 550). Sire is a calling to pay honor to the king which presented by people around him.

In characterization as the prisoner (page 310) found two signs of index that showed Louis XIV as prisoner. Why he is mentioned as the prisoner, because his name is entered in the prison book under the name of Marchialli (page 309). Marchialli was a given nick name to Philippe when Philippe was imprisoned in Bastille. Thus, when Louis was entered to the prison by Aramis and Porthos, he was called Marchialli and brought to the prison-room where for six long years Philippe had bewailed his fate. The next sign which gives index is he must suffer much 
hardship in prison, especially when he has drunk so deeply of the cup of pleasure (page 200). We have known that Louis XIV is the king of France.

The character of Philippe of France has three characterizations: In characterization as the iron mask found two signs of index. The first index is his face is covered with a mask of iron which is forbidden to remove under the pain of death (page 373). It is caused by his brother's fear about the continuing of the monarchy. He used the mask all the times, and the musketeers ready to kill him if he removed his mask. He ate in mask, slept in mask, and eventually died in mask. The second index is He is conducted by D'Artagnan hither masked (page 415). Wherever he went and whatever he did he would use the mask in order to hide his face that similar with the king's face.

In characterization as the prisoner (page 179) found two signs of index that show the reason why he is called as a prisoner. The first index is he has neither liberty, money, nor interest at his back (page 198). It was caused of his hopelessness and suffering that he had been shut up for long six years in the prison without knowing his mistaken. The second index is he had been shut up in Bastille for ten years (page 238). After his father died and Louis XIV knew about Philippe whom lived in a nobleman house in a far remote place, then he was imprisoned in Bastille where he lived his life in so much suffer and in the dark room while the cruelest of all is he had been obliged to put out his candle.

In characterization as the king's brother (his twin) found two signs of index that show the reasons why he is called as the king's brother. The first one is he is the twin of the king (page 196). He and the king Louis XIV are twins. The twins' father, Louis XIII feared the brothers would grow up to fight over the throne, so he sent the second born baby away to be raised in secret. The second one is he had been given the same noble cast of countenance, the same height and carriage, even the same feature, shape, age, and voice of his brother (page 256 and 343). He and Louis XIV are identical twins. The last one is Aramis called him "Your royal highness", a title for a brother of the king, a prince (page 253). That title is only given to the person whom is known as the prince. It is given as honorable mention to the king's son.

The character of Aramis has two characterizations: In characterization as priest (page 180) found two signs of index. The first index is he always presents the gospel (page 177). He also always asks people to pray to God in order they have forgiveness and peaceful from the God. The second index is he gives the benediction for Philippe "God have you in His holy keeping (page 252). It came from his guilty about the suffer that Philippe had got for so long because he was the only musketeer who knew that the king's son were twins and he got nothing to do to save Philippe at the time.

In characterization as the king maker (page 375) found one sign of index that shows the causalities relation why he is said as the king maker. The index is he substitutes the prisoner in the place of the king (page 345). He was the only musketeer who knew about the birth of the twin sons of the late king. He made Philippe to be the king while Louis XIV dethroned and entered to Bastille.

The character of D'Artagnan has two characterizations: In characterization as the captain of musketeers (page 172) found three signs of index. The first index is he paid the utmost attention to the military division of the king's households (page 172). It was his duty as the captain of King's musketeers. The second index is he has guards and musketeers of the king (page 285). As the captain of the musketeers he had been given a right by the king to handle all the musketeers and guards. The third index is he has the custom of the chief officers, with his sword and cloak, pistols and horses (page 547).

A loyal defender (page 414) has two signs of index. The first index is he who has served the queen mother so well and faithfully and to whom the crown of France is so much indebted as really to owe everything to him (page 264). It was because he was the only person from the late king's musketeers who stayed beside the king and he had been attached to the king's person for the last thirty years and had given the king thousands proofs of his devotion. The second index is he is as faithful as a dog although he bites occasionally (page 287). He keeps the state secret as the king wants it. But when he disagreed with the king's word he will act against his king.

The character of Athos has two characterizations: In characterization as Raoul's father (page 388) found one sign of index. The index is his son's name is Raoul de Bragelonne (page 378). Raoul was the only son of him whom he loved so tenderly and they always live together.

In the most honorable man in France (page 360) found two signs of index. The first index is he is the most worthy gentleman in the kingdom (page 398). All people in the kingdom regarded him as a good nobleman. The second index is the king himself without ever having asked any favors in return. He has never wronged anyone in the world, and the kings have been under obligations to him (page 129). He should have had the happiness of 
dying for the royal house of France as the proof of his high loyalty. But finally he got the bad attitude from the king, when the king took his son's fiancée, Louise de la Valliere. He begged the king to free Louise but the king refused it. So he lost his belief to his king.

The character of Porthos has one characterization: In the giant (page 304) found two signs of index. The indexes show us the causalities relation between the sign itself (index) with the referenced object (characterizations). The first index is he is a big man (page 305). Among the three musketeers, he was the biggest in his body. His body in the size of Godzilla's and he has the huge hand. The second index is he is too heavy (page 511). Because of the size of his body that big as Godzilla, therefore if he treads so heavily, he will break in the flooring.

The character of Raoul de Bragelonne has two characterizations: In characterization as a broken man (page 427) found two signs of index. The first index is his love is stronger than his will; he has no strength left to combat it (page 389). He loved so much his fiancée, Louise, which his heart was dead without her. He has lost his faith in everything; life is a blank for him and he thought that he has nothing anymore to live for. The second index is he was so far carried away by his lust for fighting (page 584). When he followed monsieur de Beaufort to war, he had one aim that he wanted to express his wound through fighting his enemy in the war. The wound of his was from Louise's infidelity.

In soldier (page 377) found one sign of index that can show us the causalities relation between the referenced object (characterization) and the sign (index). The index is he wore the white and blue uniform of the soldiers of the Picardy regiment, with long spikes and blue staves also with the muskets with the fleurde-lis branded on the stock (page 576). All of that were the characteristics of a soldier who would go to war. Each class or regiment of the soldiers had different uniform.

The character of Louise de La Valliere has two characterizations: In characterization as mistress of the king (page 137) found two signs of index. The first index is she is the king's lover (page 293). The king had proclaimed her as his mistress, the heavier would become the coronet of shame which she wore on her head in place of a crown even the king would never marry her. The second index is she has been a favorite of the king (page 393). The king himself had no doubt of her affection and that Louise loved him so passionately until the entire world knew it.

In Raoul's fiancée found two signs of index that show us the causalities relation between the sign itself (index) and the referenced object ( characterization). The first index is she was engaged to Raoul (page 89). They were a happy couple and they would marry after Raoul finished his duty as a young musketeer. The second index is Raoul was desirous of contracting a marriage with her (page 125). Raoul loved her more than his soul. He cannot live without Louise and he wanted to make her his. But then the king fell in love with her, so she forgot all about her vows to Raoul and turned her face to the king.

The Index Analysis of Characterizations of Minor Characters: The character of Anne of Austria has two characterizations. In the characterization as the queen mother (page 190) found one sign of index. The index is she is the mother of the present king of France, Louis XIV (page 358). She was the mother of the king whom rules the monarchy of France in the present moment after the death of his husband King Louis XIII.

In the guilty mother found one sign of index. The index is she has been guilty of a crime in making a wicked distinction between those whom nature has made so much alike (page 200). This feeling came to her after she had allowed the second born child (Philippe) to vegetate far removed from his surroundings, she deserved to be stigmatized as a heartless mother.

The character of Madame de Chevreuse has one characterization: In her characterization as old friend to the queen mother (page 452) can be found two signs which give indexes that she comes to her characterization. The first index is the queen mother has long since ceased to be her friend, but the queen mother might easily renew their friendship if opportunity were afforded her for doing so (page 21). She used to call the queen mother as her little sister in the days gone by and that she was the only person beside Her majesty, to whom the secret was known. The second index is she always regarded the queen mother with the tenders' affection (page 21). No one had ever loved the queen mother so well, and served her as faithfully as Madame de Chevreuse. That indexes show the causalities relation with her characterization.

The character of Nicholas Fouquet has three characterizations: In characterizations as finance minister of France (page 270) found two signs of index. The first index is he handled the public money (page 60). He must pay full attention to the circulation of the money that circulating around the kingdom. It was his duty as the finance minister of France. The second index is he renders an account of his stewardship to the state and the king 
(page 72). The money which he held was not only for the king himself but also for all of the people in the kingdom and the goodness of the kingdom.

In Traitor (page 294) found two signs of index. The first index is he has stolen money from the king (page 293). He accounted for the expenditure of something like thirteen million. The second index is he tried to make love to La Valliere, mistress of the king (page 317). Even he had been old but he still wanted to take a young beautiful as his mistress and had even dared to attempt to take the king's mistress, Louise de la Valliere.

In the owner of the Chateau-of Vaux-le-Vicomte (page 316), it is found three signs of indexes. The first index is it was built by Fouquet (page 267). He built it for making it as the rest house and squandered millions upon the erection of the palace. The second index is he is the master of the house (page 318). The house was belonging to him. He built that lovely palace until his last penny. The third index is he gives his undivided attention to the preparations for the splendid fete at Vaux, which one day be spoken of as being, the most magnificent incident in his career (page 73). It was quite right that this Fouquet's lovely palace had inspired King Louis XIV to build Versailles, the spectacular French palace of Versailles. It was one of reasons Louis XIV is so well remembered today.

The character of Marie Theresse has only one characterization: It gives two indexes that she is the Queen (page 276). The first index is she is called her majesty (page 596). Her majesty is an honorable mention or calling to the wife of the king where the king's honorable mention is his majesty. The second index she is the wife of the king Louis XIV (page 596). We have known that the king's wife will be said as the queen. That is why she is called the queen because she is the wife of the king.

The character of Henrietta d' Orleans has one characterization: In King's sister in law (page 121) found one sign of index. The index is her husband is a brother of the king (page 263). He married with king Louis XIV's brother and the king himself usually called her "sister". In Princess (page 603) found two signs of index. The first index is her brother is King II of England (page 601). Actually she was a princess of England but then she married with brother of King of France, so she stayed in France. The second index is she is called "Your Royal Highness" (page 87). As what has been said before that "your royal highness" is honorable mention for the child of the king, whether it is prince or princess.

\section{Conclusion}

The index analysis of characterization found in the novel the Man in the Iron Mask by Alexandre Dumas can show us the signs and the referenced objects which have causalities relation (in the more comprehensive meaning). In other words, signs which give index that the characters suitable with his or her characterizations were found. Characterization is the psychological side of the character which appears when the character comes to its development. In the novel the Man in the iron Mask by Alexandre Dumas can be found 108 characterizations, where 79 characterizations taken from eight major characters and 29 characterizations taken from 14 minor characters. Then, 44 of 108 characterizations from major (16 characterizations from eight characters) and minor characters (eight characterizations from five characters) are regarded as the representative in this study. Since semiotics is the study of signs and novel is a literary work, it is expected that English literature lecturers and students could enrich knowledge of analyzing literary works through semiotic analysis.

\section{Acknowledgements}

With such an endless sincere thank, this article is dedicated to my beloved parents. I am grateful to Dra. Hj. A. Rukayah A.Yahya, M. Pd for her comments, discussion and suggestions. Needless to say, responsibility for this version lies with me.

\section{References}

Atmazaki. (1990). Ilmu Sastra Teori danTerapan. Padang: Angkasa Raya.

Boulton, M. (2005). Icons, Symbols and a Semiotic Web. Retrieved May 22, 2013, from $\mathrm{http}: / /$ www.markboulton.co.uk/journal/icons-symbols-and-a-semiotic-web

Christomy, T., \& Untung, Y. (2004). Semiotika Budaya. Depok. Pusat Penelitian Kemasyarakatan dan Budaya. Direktorat Riset dan Pengabdian Masyarakat Universitas Indonesia.

Cobley, P., \& Litza, J. (1997). Semiotics for Beginner. United Kingdom: Cambridge, Icon Books Ltd.

Desmedt, N. E. (2011). Peirce's Semiotics/Signo Online. Retrieved May 22, 2013, from http://www.signosemio.com/peirce/semiotics.asp

Golden, J. M., \& Gerber, A. (1990). A Semiotic Perspective of Text: The Picture Story Book Event. Journal of 
Reading Behavior, 22(3), 203-219. http://dx.doi.org/10.1080/10862969009547707

The Man in the Iron Mask by Alexandre Dumas. (2013, May 22). In Barnes, \& Noble (Eds.). Retrieved from http://www.barnesandnoble.com/w/the-man-in-the-iron-mask-by-alexandre-dumas-alexandre-dumas/11091 36623\#

Jegede, O. B. (2003). A Semiotic Study of Court Poetry Performance in Nigeria: Text and Context. International Journal of African and African American Studies, 5, 199-222. Retrieved from http://www.brunel.ac.uk/_data/assets/pdf_file/0017/110744/Olutoyin-Bimpe-Jegede,-A-Semiotic-Study-of -Court-Poetry-Performance-in-Nigeria-Text-and-Context--an-illustrated-essay.pdf

Mackey, S. (2012). Semiotic, Rhetoric and Democracy. Cosmos and History. The Journal of Natural and Social Philosophy, 8(1), 304-322. Retrieved from http://cosmosandhistory.org/index.php/journal/article/view/275

Norgaard, N. (2009). The Semiotic of Typography in Literary Texts: A Multimodal Approach. Blackwell Publishing: Orbis Litterarum Journal, 64(2), 141-160. http://dx.doi.org/ 10.1111/j.1600-0730.2008.00949.x

Ratna, N. K. (2004). Teori, Metode, dan Teknik Penelitian Sastra. Yogyakarta: Pustaka Pelajar.

Shitemi, N. (2009). Discourse on Semiotic and Functional Perspectives of Narratology. The Journal of Pan African Studies, 2(8), 76-106. Retrieved from http://www.jpanafrican.com/docs/vol2no8/2.8_DiscourseonSemioticandFunctionalPerspectivesofNarratolog y.pdf

Sobur, A. (2004). Semiotika Komunikasi. Bandung: PT Remaja Rosdakarya.

Tarigan, H. G. (1984). Prinsip-prinsip Dasar Sastra. Bandung: Angkasa.

Wannisinghe, J. (2011). Semiotic Analysis of Short Message Service (SMS). International Journal of Communicology, 1(1), 11-19. Retrieved from http://spc.cmb.ac.lk/journal/images/article2.pdf

Wannisinghe, J. (2002). Wordsworth Classics. The Man in the Iron Mask: Alexandre Dumas. Hertfordshire: Wordsworth Edition Limited.

\section{Copyrights}

Copyright for this article is retained by the author(s), with first publication rights granted to the journal.

This is an open-access article distributed under the terms and conditions of the Creative Commons Attribution license (http://creativecommons.org/licenses/by/3.0/). 